\title{
The Model Construction of English Ecological Class in the High School in China
}

\author{
Zhen Zhou ${ }^{1}$ \\ ${ }^{1}$ Foreign Language School, Nanchang Normal University, Nanchang, Jiangxi, China \\ Correspondence: Zhen Zhou, Foreign Language School, Nanchang Normal University, Nanchang, Jiangxi, \\ China. Tel: 15083549166. E-mail: zoye100@sina.com
}

Received: July 21, 2017 Accepted: August 18, 2017 Online Published: August 21, 2017

doi: 10.5539/elt.v10n9p227 URL: http://doi.org/10.5539/elt.v10n9p227

\begin{abstract}
The Ecological class is a kind of class in which the system of class teaching is in a state of dynamic balance and it can enhance the efficiency of class teaching. The article analyzes the feature of English ecological class, illustrates the non-ecological class teaching problems and explores the ways to establish English ecological class from the five aspects such as: teaching environment, the relationship between the teacher and students and the relationship between students and students, teaching methods, teaching content, and teaching evaluation, so as to improve the English teaching effect of the high school, and to provide some reference for the English teaching in the high school.
\end{abstract}

Keywords: ecological class, teaching environment, teaching method, teaching content, teaching evaluation

\section{Introduction}

As early as in 1930s, American educator Waller (1932) first proposed the concept of "class ecology", and then the study of educational ecology gradually attracted close attention of many experts and scholars. At present, the research of educational ecology has become a hot topic in the field of educational research, and the study of ecological class has become the focus of the study of educational ecology. The ecological class is a unit formed through interaction of society and psychology based on ecology theory with dialectical thinking of the relationship between students and teachers in the classroom teaching environment. It is a way of thinking and developing idea with the core value of the harmonious relationship of human and human, human and environment. The ecological class is to organize the classroom teaching with the teaching concept of integrity, life and development, and it is basically consistent with the English teaching guided by China's new curriculum requirements. The ecological class stresses the "symbiosis" relationship of teachers and students, and it teaches for the development of teachers and students as well (Sun, 2006; Liu, 2010; Du, 2012; Shi, 2014; Wang, 2017; Xiong, 2017). The ecological class is not completely opposed to the traditional class teaching, but it is a change and promotion of the quality of the traditional class. It is a modern ideal teaching view, and is the goal pursued by many teachers and educators. Many scholars have made some research and achieved rich results of ecological class, and the researches mainly focus on the principles, factors, teaching mode, teaching strategies and evaluation of implementation efficiency, the development of teachers and some other aspects of research on the ecological class (Huang, 2008; Liu, 2012; Wu, 2016; Kuang, 2017; Liu, 2017).

However, the study of the ecological class covers a wide area, such as the high school language classroom, mathematics classroom, geography class, chemistry class, political class, or college English classroom, and the study on the ecological class of English teaching of high schools is particularly scarce. Besides, there are still a lot of problems to be solved in the English class teaching in the high school in China, and the teaching effect needs to be improved, and the classroom teaching mode needs to be reformed.

\section{The Main Features of English Ecological Class in the High School}

\subsection{The Overall Openness}

Nature is an interrelated and interdependent organic whole, and the high school English class is also a whole unity composed of many elements which are inseparable and interdependent with each other. "Openness" refers to the connection among the elements inside and outside the system. And the English ecological class in the high school is an open eco-system, with import, output and exchange of materials, energy and information, so as to 
update themselves and develop constantly. The integrity and openness of the English ecological class are unified, the elements are unified and closely linked, while the external favorable factors are eclectic. In the English class, all the elements of teachers, students, and environment form a whole ecosystem, and they are open to each other. Teachers and students, students and students can expand rich exchanges with each other as to the English learning, and they can also do some exchanges and communication in English with the external environment, other classes, other schools and other fields, to learn from each other and to promote their own development.

\subsection{Flexible Interaction}

The ecological class advocates flexible and diverse teaching methods to stimulate students' interest in learning. In the ecological class teaching, students' development does not only stay in the knowledge teaching and the level of ability training, but it is also a kind of interactive activities in order to achieve life development among teachers, students and teaching environment. In the process, teachers and students are enjoying the fun of cognitive development process and life growing ( $\mathrm{Du}, 2012)$. Therefore, the English teachers should adopt ecological class teaching, employ flexible teaching methods and means, and abandon the traditional teaching model of "Only teacher says, students listen. " and make the English teaching fun and meaningful. The teacher should let students explore and learn how to learn, and emphasize stimulating students to thinking more and critically, design more interactive activities between teachers and students, pay attention to the ecological value of life, cultivate students' interest, and improve the quality of teaching, so that teachers and students can achieve common sustainable development.

\subsection{Individual Differences}

The English Class is not the factory turning out qualified talents, and students are not "products" on the assembly lines. The core of ecological class teaching is "people-oriented", respecting individual differences and the students' subjective emotional experience and caring about the development of each student. As early as 2000 years ago, Chinese ancient educator Confucius advocated the concept of "individualized teaching", and the American educator Gardiner also proposed the theory of "multiple intelligences", which also claimed that our education is not uniform or rigid dogma, and the teacher should respect the different characteristics of each student, should love students, and should carry out targeted and individualized teaching for students, and should help students to find suitable methods to learn English effectively so as to realize their potentials.

\subsection{Harmonious Symbiosis}

In the high school classroom, the harmony of ecological class mainly refers to the relationship of the subject in the classroom teaching between teachers and students, teachers and colleagues, also includes the harmony among students, teachers, and classroom teaching environment. The English ecological class in the high school is a harmonious class which promotes the continuous growth of the teacher and students in which teachers are always full of positive energy and enthusiasm, and students are full of learning and exploring passion, and teachers and students inspire each other. The class becomes a "Happy Paradise" and the teaching benefits teachers as well as students. The classroom is no longer boring, but a harmonious learning atmosphere comes into being between teachers and students, among students, and among teachers, students and teaching environment. Students' learning becomes more relaxed, natural, and happy, which promotes the harmonious, orderly, and sustainable development of the class teaching.

\subsection{Sustainable Development}

The essence of "sustainable development" in the ecological class teaching of high school is that teachers, students, classroom teaching environment and other factors work together to achieve common and lasting development. In the English ecological class in the high school, in order to promote the sustainable development of students' learning ability, the most important things teachers should do are as follows: First, teachers should stimulate students' interest in learning English and can make them sustain interest. The teacher should change their traditional teaching way of "chalk and talk", and make the students take the initiative to learn. Only in this way can learning be full of motivation and vitality and can learning achieve a sustainable development; Second, the teacher should cultivate students' autonomous learning ability, and teach students how to learn well and effectively. Like a Chinese saying goes, it is better for teachers to teach students how to fish than offer them fish. Only in this way can English learning be more effective and can attain a sustainable development; Third, teachers and students should communicate frequently, teachers should pay more attention to the students' thoughts, protect the self-confidence of students, and students' English should not be guided by the teacher's preferences and they should have their own inner integrated learning motivation. 


\section{Non-ecological Situation in the English Classroom in the High School}

At present, it is a common phenomenon that the English classroom teaching in the high school in China is not ecological. These factors such as the English classroom environment, teacher-student relationship, teaching content, teaching methods, teaching evaluation have caused the non-ecological status of the English classroom teaching.

\subsection{Non-ecological Classroom Environment}

On the one hand, the simple and tedious classroom environment can not promote students' study and cannot make students resonate. A blackboard, a podium, rows of classroom desks and chairs are immutable and frozen, and this environment cannot stimulate students' learning enthusiasm, but imprisons the students' thinking and imagination, and it cannot achieve good result. Besides, the number of students in a class is too large in the high school in China, and there are usually more than 50 students in a class. This will undoubtedly reduce the effectiveness of teaching greatly, increase the difficulty of teaching, and it is also contrary to the principle of moderation in ecology.

\subsection{Non-ecological Relationship between Teachers and Students}

Many English teachers in the high school are too authoritative and they think all that they say and do are right, and they do not allow students to refute or put forward the personal view, the students have to keep silent or keep their opinions, and they have little communication with teachers, resulting in the lack of communication between teachers and students, and cold relationship between them. Some English teachers are impartial to students and favor students with high scores, and often make good students answer questions or provide more opportunities for their performance, and academically backward students are ignored. This non-ecological relationship between teachers and students is not conducive to the healthy and positive development of students.

\subsection{Non-ecological Teaching Content}

Most of the English teaching takes the national college entrance examination as the main goal, and pays too much attention to the teaching of the language knowledge-based content. And the teaching content is devoiced from the students' actual life. The teaching has little to do with explaining the language and culture background to the students, which turns out students with higher scores but great difficulty in using English to communicate freely in real life. Furthermore, the teaching content is carried out in a closed language environment, with little ecological information exchange with the outside world. At the same time, in the closed language environment, the students lose their creative ability and their teaching resources are not fully utilized.

\subsection{Non-ecological Teaching Methods}

The English teaching theory is an important factor of ecological teaching and the disharmony between it and the ecological subject will inevitably affect the teaching environment. In the ecological classroom teaching environment, teachers and students, as the main body of the ecological system, should cooperate with each other and develop together, so as to promote the effective flow of information. However, the long-term influence of test-oriented English teaching in China, it is difficult to really integrate into the new curriculum teaching idea, and teachers still adopt the knowledge model, mainly explain knowledge, and the students carefully take notes, occasionally answer questions. The traditional teaching concept hinders the flow of information within the ecosystem, and lively, interesting English class becomes boring and lifeless.

\subsection{Non-ecological Teaching Evaluation}

Only a reasonable ranking can ensure the balance and stability of the ecosystem. At present, English teaching is still dominated by teachers' unilateral evaluation, and the evaluation standard is too single, in which teachers establishes an authoritative image, ignores students' ecological status, so it is difficult to arouse the students' learning interest. At the same time, the results of the evaluation pay too much attention to the examination results, while ignoring language communication ability, emotional attitude, creative ability and other factors. This evaluation standard leads to the overlap of students' niche in ecological teaching environment, and there is a mutual exclusion among students, and it is difficult to carry out cooperative learning, so it is difficult to achieve sustainable development of personality.

\section{The Strategy of Constructing an English Ecological Class}

The ecological class is a kind of teaching ecological system regarding students, teachers, learning content, learning methods, learning evaluation and learning environment as a whole unit, and establishes a classroom form of a holistic, open, diverse, harmonious, and sustainable development, which is a classroom type fit for students' physiological characteristics and learning and living habits. 


\subsection{Ecological Teaching Environment}

The ecological teaching environment is natural, and harmonious with the natural state of teachers and their aesthetic needs. The teaching environment includes physical environment and human environment. The physical environment is particularly important, which is the most basic condition of learning. The school should provide comfortable teaching environment, in which the classrooms have bright windows and clean tables with soft colors and natural fresh air. The ecological class should break the traditional "nursery" seating arrangements, and arrange seats flexibly according to the actual situation. The class size should be moderate, for example, the oral English teaching should use a small-size class teaching. The teacher should improve the ecological environment of the classroom, and only in this way can teaching be always full of vitality, and the teaching effect can be improved significantly. The ecological environment of the classroom culture is very important for the English learners, which will play a subtle role. The teacher should create a strong English learning atmosphere in the class, create harmonious ecological humanistic class through guiding the students to carry out lectures, seminars, cultural festival, knowledge contests, drama, English singing competition, English calligraphy contest, English debate, English advertising design contest and other activities.

\subsection{Ecological Relations between Teachers and Students}

The traditional classroom is teacher-centered, in which the teacher is the authority of knowledge, and teachers impart knowledge to students. While the students are knowledge container and test machine, so the teaching kills many students' learning desire. But the ecological class is one that emphasizes the symbiosis between teachers and students, and promotes the common development of both teachers and students. The ecological relationship between teachers and students is a new teacher-student relationship. Teachers as one of the main factors of teacher-student relationship, and play a leading role in improving the relationship between teachers and students. And teachers should treat the students equally and fairly, care for students, and respect students' individual differences, teaching in accordance with their aptitude. The relationship between students and students should also be the relationship of ecological harmony, with strong solidarity, mutual supervision, mutual learning, mutual encouragement and common progress, racing each other, and forming a positive atmosphere.

\subsection{The Ecological Teaching Content}

The teaching material is the foundation and center of the classroom teaching, but it does not mean that the teachers teach simply what the textbook says. Teachers should learn to select and adapt teaching resources and teaching content according to the students' English level, cognitive characteristics, hobbies and personality characteristics, and should conduct necessary additions or changes to optimize the integration of teaching content. Furthermore, teachers should devote to studying materials, make flexible and creative use of teaching materials, textbooks, and make teaching materials full of vitality, and only in this way can students learn in the best of spirits. For example, when teaching the unit "color", teachers can expand the Chinese famous cartoon story of "Baby gourd", how the colors of the fireworks come, and different cultural connotation of color words in the West and in China and so on. It can not only enhance the students' cross-cultural awareness, but also increase students' interdisciplinary knowledge, and make students understand that language is a fantastic tool through which we can know more about this wonderful world.

\subsection{Ecological Teaching Methods}

The traditional teachers in the high school teach English in some boring ways, mainly adopt the grammar translation method, pay attention to the language structure, and regard grammar and vocabulary teaching as the core. The translation of sentences and rote learning are the main teaching ways, and it can train the students' exam-tackling ability, but students' practical ability is deficient. So it is difficult for this method to achieve the symbiotic development of students and to achieve the sustainable development of teaching. The goal of high school English teaching that the new curriculum puts forward is to train students' comprehensive English application ability. And the new situation and new era background call for the ecological teaching method. The ecological teaching method means that the teachers should adopt suitable and flexible teaching methods, find suitable teaching method for students. Teachers can use various kinds of teaching methods, such as the communicative language teaching method, task-based language teaching method, total physical response method, audio-visual method, group cooperation method, reading method, vocabulary method and overall method, content method and so on. Only the teaching ways are ecological, can students' learning be ecological.

\subsection{Ecological Teaching Evaluation}

The teaching evaluation is a means to test the teaching situation, and it reflects the effect of classroom teaching. The core of ecological class is the sustainable development of teaching. And to achieve this goal, the ecological 
teaching evaluation is critical. The traditional teaching evaluation is unilateral, that is, merely teachers' evaluation of students. And the evaluation of ecological class requires that teachers and students evaluate together, and teaching benefits teachers as well as students. Firstly, students, parents and schools evaluate teachers and put forward the corresponding opinions and suggestions, in order to promote the teaching progress. Secondly, the evaluation of students' learning should be comprehensive, unbiased, and appreciating. And the formative evaluation and summative evaluation should be combined together. The teachers should pay more attention to students' progress and growth in the English learning process. Furthermore, the learning evaluation should get out of the vicious circle of "rote learning" to focus on training students practical language ability. And the learning evaluation should be diverse, that is, the students themselves, classmates, teachers and parents all should be involved in the evaluation of students, so as to promote the growth of students.

\section{Conclusion}

The English teaching in the high school is a micro educational ecosystem, in which the class teaching follows the ecological law. Only when the various elements achieve an ecological balance, can the English teaching achieve a sustainable development. To create a harmonious ecological class of high school English teaching, first of all, the physical environment and the humanistic environment should be ecological; Secondly, we should change the traditional teacher's authority, "cramming" status, and unequal relationship between teachers and students. Secondly, we should build a harmonious and pleasant teacher-student relationship and student-student relationship; Teachers should integrate the teaching content scientifically and reasonably, stimulate students' interest, cultivate students' comprehensive language ability. Thirdly, teachers should also keep learning and improve their teaching methods. Finally, the teaching evaluation should be open and pluralistic, paying attention to each student's progress from multiple perspectives.

\section{References}

Du, Y. L. (2012). Implementation strategy of ecological class concept construction in primary and secondary schools. Modern Educational Science, 4, 128-129.

Huang, J. G. (2008). The strategies to construct ecological class. China Adult Education, 7, 120-121.

Kuang, Y. (2017). The establishment of ecological classroom teaching model for junior middle school English. Basic Education Research, 10, 28-30.

Liu, D. D. (2010). Ecological class study of junior high school English. Journal of Inner Mongolia Normal University, 6, 112-114.

Liu, K.W. (2012). Connotation, mode of operation and implementation strategy of ecological class. Teaching and Management, 1, 14-16.

Liu, S.Y. (2017). Constructing a harmonious English ecological classroom. Middle School English, 22, 106-107.

Shi, Y. (2014). The function of code switching in the construction of English ecological classroom. Heilongjiang Researches on Higher Education, 2, 155-157.

Sun, F. R., Xie, L. M. (2006). Review of classroom ecology abroad. Foreign Primary and Secondary Education, $6,12-18$.

Waller, W. (1932). The Sociology of Teaching. New York: Russell and Russell. https://doi.org/10.1037/11443-000

Wang, X. J. (2017). How to construct the ecological classroom evaluation system in the five year higher vocational education in the view of educational ecology-taking tourism management major as an example. Time Education, 5, 64-65.

$\mathrm{Wu}$, X.Y. (2016). Construction of College English ecology class. Journal of Liaoning Broadcast and TV University, 2, 49-50.

Xiong, J. J. (2017). Optimization study of English ecology classroom teaching. Teaching and Management, 3, 110-112.

\section{Copyrights}

Copyright for this article is retained by the author(s), with first publication rights granted to the journal.

This is an open-access article distributed under the terms and conditions of the Creative Commons Attribution license (http://creativecommons.org/licenses/by/4.0/). 